\title{
Economics
}

The Open-Access, Open-Assessment E-Journal

Vol. 12, 2018-54 | August 20, 2018 | http://dx.doi.org/10.5018/economics-ejournal.ja.2018-54

\section{Temporary exports and characteristics of destination countries: first evidence from German transaction data}

\author{
Joachim Wagner
}

\begin{abstract}
This paper uses information on all export transactions of goods by German firms with countries outside the European Union from 2009 to 2014 to document for the first time the patterns of export participation at the firm-good-destination level over time and to investigate the link between the duration of export patterns and characteristics of destination countries. It turns out that only 6.5 percent of all combinations were recorded in each year, while more than half of all patterns are only observed once. In line with theoretical hypotheses, the likelihood of permanent trade patterns increases within a firm with proximity and market size of destination countries.
\end{abstract}

JEL F14

Keywords Temporary exports; permanent exports; transaction level data; Germany

\section{Authors}

Joachim Wagner, Leuphana University Lueneburg, Germany; CESIS, KTH Stockholm, Sweden,wagner@leuphana.de

Citation Joachim Wagner (2018). Temporary exports and characteristics of destination countries: first evidence from German transaction data. Economics: The Open-Access, Open-Assessment E-Journal, 12 (2018-54): 1-12. http://dx.doi.org/10.5018/economicsejournal.ja.2018-54

Received March 26, 2018 Published as Economics Discussion Paper May 5, 2018 Revised August 7, 2018 Accepted August 10, 2018 Published August 20, 2018

(c) Author(s) 2018. Licensed under the Creative Commons License - Attribution 4.0 International (CC BY 4.0) 


\section{Motivation}

A growing literature that is based on data for exports at the transaction level which include information on which goods of which value and which weight are exported by which firms to which destination countries in a year ${ }^{1}$ documents that export relationships tend to be highly dynamic in the short run. Using data for Chile, Álvarez, Faruq and López (2010) report that an important fraction of firms start to export new products to new markets each year. Previous experience in exporting a certain product, or exporting to a certain market, increases the probability to export these products to new markets, or new products to the same markets. Again for Chile, Blum, Claro and Horstmann (2013) find that one third of exporters enter into and exit from exporting multiple times, and that most continuing exporters enter and exit specific export destinations multiple times. Rahu (2015) reports that in Estonia adding and dropping new products in exports is rife, with about half of all firms changing their export portfolio annually. Similarly, Buono and Fadinger (2012) find that export relationships are highly dynamic in France, where a large fraction is created and concluded each year. For Hungary, Békés and Muraközy (2012) report that about one third of firm-destination and about one half of firm-product-destination export spells are temporary only. Amador and Opromolla (2010) document frequent switching of products and destinations by firms. Similarly, Damijan, Konings and Polanec (2014) report that in Slovenia the average firm changes about one-quarter of imported and exported product-markets every year. For Spain, Esteve-Pérez, RequenaSilvente and Pallardó-Lopez (2013) find that, while firm export status is highly persistent, firms' destination portfolio is very dynamic with a median duration of firm-country exporting relationship of two years, but the risk of exiting sharply falls afterwards. Geishecker et al. (2017) report that in Denmark one third of all firm-product-destination export spells are isolated single-month, one-off export transactions that are observed only once in a 49-month time window.

This high degree of short-lived export spells at the firm-good-destination level ${ }^{2}$ comes as a surprise because export activities incur sunk costs (e.g., for market research, adoption of the product to local conditions, or finding partners to trade with) that a firm has to pay for each good exported to each market at the start of an export relationship. "As this sunk cost is an investment that can only be recovered from a stable stream of revenues, firms are expected to export a given product to a given destination over a long period of time.” (Békés and Muraközy 2012, p. 232).

Evidence cited above point out that, contrary to this, firms often do not export a given product to a given destination over a long period of time, at least not in the countries looked at hitherto. This paper contributes to the literature by adding evidence for Germany, the third largest actor on the world market for exports of goods - keeping in mind that "the credibility of a new finding that is based on carefully analyzing two data sets is far more than twice that of a result based only on one" (Hamermesh 2000, p. 376). It uses information on all export trans-

\footnotetext{
1 See Wagner (2016) for a comprehensive survey of 147 empirical studies that use transaction level data on exports or imports.

2 See Nitsch (2009) for empirical evidence on the often short duration in German import trade at the 8digit product level from 1995 to 2005.
} 
actions of goods by German firms with countries outside the European Union from 2009 to 2014 to document the patterns of export participation at the firm-good-destination level over time. Furthermore, it investigates the link between the duration of export patterns and characteristics of destination countries.

The rest of the paper is organized as follows: Section 2 introduces the transaction level data for exports of goods in Germany. Section 3 presents descriptive evidence on the frequency of patterns of exports over the years 2009 to 2014. Section 4 reports results from an econometric investigation of the hypothesis put forward by Békés and Muraközy (2012) that the likelihood of a long trade spell increases with proximity and market size of destination countries.

\section{Transaction level data for exports of goods in Germany}

In Germany information on the goods traded internationally and on the countries with which these goods are traded is available from the statistic on foreign trade (Außenhandelsstatistik). This statistic is based on two sources. One source is the reports by German firms on transactions with firms from countries that are members of the European Union (EU); these reports are used to compile the so-called Intrahandelsstatistik on intra-EU trade. The other source is transactionlevel data collected by customs on trade with countries outside the EU (the so-called Extrahandelsstatistik). ${ }^{3}$ The raw data that are used to build the statistic on foreign trade are transaction level data, i.e. they relate to one transaction of a German firm with a firm located outside Germany at a time. Published data from this statistic report exports or imports aggregated at the level of goods traded and by country of destination or origin.

The data used in this paper are based on the raw data at the transaction level. The unit of observation in these data is a single transaction between economic agents located in two countries, e.g. the export of $\mathrm{X}$ kilogram of good A with a value of $\mathrm{Y}$ Euro by firm $\mathrm{Z}$ from Germany to China. The data cover 24,885,099 transactions in 2009 and 35,120,715 transactions in 2014.

The data cover trade with 243 different countries. For a given year, the sum over all export transactions is identical to the figures published by the Federal Statistical Office for total exports of Germany.

The record of the transaction usually 4 includes a firm identifier (tax registration number) of the exporting firm. Over the years 2009 to 2014 the data used include information on export activities of 188,581 different firms. Using the firm identifier information at the transaction level can be aggregated at the level of the trading firm to generate year-firm-product-value-

\footnotetext{
3 Note that firms with a value of exports to EU-countries that did not exceed 400,000 Euro in the previous year or in the current year do not have to report to the statistic on intra-EU trade. For trade with firms from non-member countries all transactions that exceed 1,000 Euro (or have a weight that exceeds 1,000 kilogram) are registered. For details see Statistisches Bundesamt, Qualitätsbericht Außenhandel, Januar 2011.

4 Note that this identifier is missing for 0.67 percent of all export transactions and 1.2 percent of all import transactions for various reasons including that traders do not have a (German) tax identification number. Further details were not revealed to me.
} 
weight-destination data. The firm identifier can be used to link information on export transactions of a firm over time, too.

In the transaction level data products are distinguished according to very detailed classifications. In the data used for this study the Harmonized System at 6-digit level (HS6) is used as the product classification system. The data cover 5,370 different goods in exports.

The Federal Statistical Office prepared this type of data for the reporting year 2009 for the first time; the most recent data available at the time of writing this paper are for 2014.

The transaction data can be used to identify all firm-good-destination combinations in a year and to document for each combination whether it has been recorded in a certain year between 2009 and 2014 or not. For example, firm A may have exported good B to country C in year 2009 and 2011, but not in the years 2010, 2012, 2013 and 2014. As explained in footnote 3 above for exports to countries that are members of the EU there is a reporting threshold so that export transactions of firms with exports below this threshold are not recorded. For firm-gooddestination combinations of these firms this may lead to an incorrect classification of a combination as non-existent in the respective year. Therefore, in this paper we will only investigate export transactions with non-EU countries. ${ }^{5}$ Here all transactions that exceed 1,000 Euro (or have a weight that exceeds 1,000 kilogram) are registered and, therefore, the problem of "false zeros" does not vanish completely but is much less severe.

\section{Patterns of exports by firm-good-destination over time}

In a first step it is documented how many firm-good-destination transactions were recorded by the customs in different combinations of years between 2009 and 2014. We call each different combination of years a pattern and label it with a six-digit number made of zeros and ones, where 0 indicates a year in which the respective firm-good-destination transaction was not recorded and 1 indicates a year in which we observed this transaction. The first digit refers to 2009, the second to 2010, and so on. The pattern 000001, therefore, refers to all firm-gooddestination combinations that were only recorded in 2014, 101000 refers to firm-gooddestination combinations that were recorded in 2009 and 2011 (but not in 2010 and not in 2012 to 2014), and 111111 refers to all firm-good-destination combinations that were recorded in each year between 2009 and 2014. This leads to 63 different patterns of exports by firm-gooddestination over the six years.

Table 1 reports the frequency of each pattern and its percentage share in all patterns for all goods exported to non-EU destination countries between 2009 and 2014. In total, there were 8,945,032 firm-good-destination combinations. Only 583,995 (or 6.53 percent) of these combinations were recorded in each year. Permanent export in the sense of exports of one good by one firm to one destination country in each year, therefore, is rare. On the other hand, $51.33 \%$ or more than half of all patterns are only observed once - one-time exports by a firm of a good to a destination, therefore, are quite common. Perforated pattern that include zeros

\footnotetext{
5 Note that Croatia who joined the EU in mid-2013 only is treated as a non-member state here.
} 
Table 1: Patterns of export of German firms in trade with non-EU countries by firm-HS6-good-destination, 2009-2014

\begin{tabular}{|c|c|c|c|c|c|}
\hline Pattern & Frequency & Percent & Pattern & Frequency & Percent \\
\hline 000001 & $1,158,683$ & 12.95 & 100001 & 19,446 & 0.22 \\
\hline 000010 & 821,741 & 9.19 & 100010 & 21,038 & 0.24 \\
\hline 000011 & 378,004 & 4.23 & 100011 & 12,345 & 0.14 \\
\hline 000100 & 833,299 & 9.32 & 100100 & 30,224 & 0.34 \\
\hline 000101 & 95,202 & 1.06 & 100101 & 6,768 & 0.08 \\
\hline 000110 & 181,360 & 2.03 & 100110 & 11,053 & 0.12 \\
\hline 000111 & 237,883 & 2.66 & 100111 & 14,061 & 0.16 \\
\hline 001000 & 780,883 & 8.73 & 101000 & 48,465 & 0.54 \\
\hline 001001 & 51,670 & 0.58 & 101001 & 6,393 & 0.07 \\
\hline 001010 & 62,390 & 0.70 & 101010 & 8,085 & 0.09 \\
\hline 001011 & 40,094 & 0.45 & 101011 & 7,068 & 0.08 \\
\hline 001100 & 170,270 & 1.90 & 101100 & 20,049 & 0.22 \\
\hline 001101 & 38,295 & 0.43 & | 101101 & 6,931 & 0.08 \\
\hline 001110 & 82,660 & 0.92 & 101110 & 13,056 & 0.15 \\
\hline 001111 & 170,641 & 1.91 & 101111 & 27,803 & 0.31 \\
\hline 010000 & 742,861 & 8.30 & 110000 & 207,387 & 2.32 \\
\hline 010001 & 33,971 & 0.38 & 110001 & 10,666 & 0.12 \\
\hline 010010 & 37,116 & 0.41 & 110010 & 11,756 & 0.13 \\
\hline 010011 & 21,506 & 0.24 & 110011 & 9,940 & 0.11 \\
\hline 010100 & 64,382 & 0.72 & 110100 & 23,040 & 0.26 \\
\hline 010101 & 15,610 & 0.17 & | 110101 & 7,148 & 0.08 \\
\hline 010110 & 24,330 & 0.27 & 110110 & 12,625 & 0.14 \\
\hline 010111 & 31,360 & 0.35 & 110111 & 22,180 & 0.25 \\
\hline 011000 & 188,015 & 2.10 & 111000 & 149,593 & 1.67 \\
\hline 011001 & 20,506 & 0.23 & 111001 & 12,650 & 0.14 \\
\hline 011010 & 25,590 & 0.29 & 111010 & 16,721 & 0.19 \\
\hline 011011 & 24,669 & 0.28 & 111011 & 21,833 & 0.24 \\
\hline 011100 & 101,317 & 1.13 & 111100 & 113,693 & 1.27 \\
\hline 011101 & 29,574 & 0.33 & | 111101 & 29,626 & 0.33 \\
\hline 011110 & 68,372 & 0.76 & 111110 & 111,980 & 1.25 \\
\hline 011111 & 195,681 & 2.19 & 111111 & 583,995 & 6.53 \\
\hline 100000 & 619,479 & 6.93 & Total & $8,945,032$ & 100.00 \\
\hline
\end{tabular}

Note: 0 indicates no transaction, 1 indicates a transaction. The first digit refers to 2009, etc. The pattern 000001 refers to firm-good-destination transactions that happened only in 2014, 101000 refers to firm-good-destination transactions that happened in 2009 and 2011 (but not in 2010 and 2012-2014), and 111111 refers to firm-good-destination transactions that were recorded in each year between 2009 and 2014.

between ones (like 111001, or 101001) tend to be rare, while patterns with some ones in a row and zeros otherwise (like 111100, or 000011, or 000111) are more common. The big picture reported here is in line with results from similar investigations reported for other countries that are summarized in the introductory section.

Why do patterns of export by firm-good-destination differ? Why do we only rarely observe permanent export on the one hand and why are one-time exports quite common on the other hand? Obviously, characteristics of the exported goods will play a role here. You will not expect a shipyard to export submarines to a certain destination country each year (leading to a pattern 111111), and you will not be surprised to learn that such an export deal did only happen once 
over a period of six years (with a pattern like 000100, or 010000). On the other hand, you might expect that, for example, Volkswagen exports cars from a given HS6-category to several destinations each year (leading to a number of patterns 111111).

For confidentiality reasons it is not possible to look at the patterns for different goods at the HS6-level separately. However, some evidence on the role of the characteristics of the exported goods for the patterns of export by firm-good-destination might be revealed by an investigation that distinguishes between goods at the HS2-level. Table 2 reports the percentage share of permanent and one-time patterns for all goods by HS2-group exported to non-EU destination countries between 2009 and 2014.

The share of permanent patterns varies widely between goods at the HS2-level. For example, while it is 6.53 percent on average it is only 0.68 percent in group 3 (fish etc.), 1.77 percent in group 66 (headgear and parts thereof) and 1.87 percent in group 10 (cereals), while it is 11.10 percent in group 50 (silk), 10.78 percent in group 30 (pharmaceutical products) and 10.44 percent in group 18 (cocoa and cocoa preparations). Similarly, the share of one-time patterns varies widely, too, between the HS2-goods. The average is 51.33 percent, and it is only 44.42 percent in group 50 (silk), 44.47 percent in group 23 (residues and waste from the food industries; prepared animal fodder) and 44.54 percent in group 30 (pharmaceutical products), but 71.09 percent in group 89 (ships, boats and floating structures), 65.34 percent in group 87 (vehicles other than railway or tramway rolling stock, and parts and accessories thereof), and 64.55 percent in group 97 (works of art, collectors' pieces and antiques). Overall, the impression is that one-time patterns are more often found for differentiated goods while they are more rarely registered for standardized goods. A similar statement cannot be made with regard to permanent patterns.

Table 2: Shares (percent) of patterns of export of German firms in trade with non-EU countries by firm-HS2-good-destination, 2009-2014

\begin{tabular}{lcccccccc}
\hline HS2 & Permanent & One-time & HS2 & Permanent & One-time & HS2 & Permanent & One-time \\
\hline 1 & 1.86 & 64.18 & 34 & 9.46 & 49.05 & 67 & 6.00 & 54.94 \\
2 & 2.40 & 58.01 & 35 & 8.34 & 50.56 & 68 & 7.54 & 54.57 \\
3 & 0.68 & 63.24 & 36 & 6.62 & 53.96 & 69 & 5.83 & 57.89 \\
4 & 4.33 & 56.11 & 37 & 6.98 & 50.96 & 70 & 6.95 & 56.23 \\
5 & 6.54 & 53.41 & 38 & 9.94 & 47.30 & 71 & 4.93 & 56.60 \\
6 & 5.96 & 52.52 & 39 & 7.52 & 52.64 & 72 & 4.91 & 60.79 \\
7 & 4.53 & 55.24 & 40 & 7.54 & 52.91 & 73 & 6.52 & 55.29 \\
8 & 5.21 & 55.26 & 41 & 7.13 & 55.33 & 74 & 7.38 & 54.73 \\
9 & 4.47 & 54.73 & 42 & 5.19 & 57.60 & 75 & 4.85 & 56.79 \\
10 & 1.87 & 58.38 & 43 & 6.27 & 55.79 & 76 & 5.80 & 57.56 \\
11 & 6.27 & 52.89 & 44 & 5.68 & 59.53 & 78 & 4.86 & 60.03 \\
12 & 8.57 & 49.14 & 45 & 8.01 & 54.18 & 79 & 7.78 & 52.21 \\
13 & 8.11 & 47.24 & 46 & 4.69 & 59.12 & 80 & 4.82 & 56.98 \\
14 & 5.83 & 59.49 & 47 & 8.62 & 60.08 & 81 & 6.80 & 53.44 \\
\hline
\end{tabular}


Table 2 continued

\begin{tabular}{lcccccccc}
\hline HS2 & Permanent & One-time & HS2 & Permanent & One-time & HS2 & Permanent & One-time \\
\hline 15 & 4.40 & 56.04 & 48 & 5.62 & 57.01 & 82 & 7.22 & 55.28 \\
16 & 3.42 & 57.79 & 49 & 6.23 & 53.88 & 83 & 8.24 & 54.55 \\
17 & 6.69 & 54.15 & 50 & 11.10 & 44.42 & 84 & 6.62 & 56.16 \\
18 & 10.44 & 48.05 & 51 & 6.03 & 52.51 & 85 & 6.27 & 56.34 \\
19 & 8.88 & 50.61 & 52 & 7.12 & 51.85 & 86 & 4.90 & 63.63 \\
20 & 6.19 & 55.67 & 53 & 8.93 & 51.35 & 87 & 3.35 & 65.34 \\
21 & 9.15 & 48.54 & 54 & 9.73 & 48.82 & 88 & 6.69 & 56.49 \\
22 & 7.74 & 51.72 & 55 & 6.94 & 53.29 & 89 & 2.24 & 71.09 \\
23 & 9.78 & 44.47 & 56 & 6.80 & 54.95 & 90 & 6.86 & 54.55 \\
24 & 5.82 & 45.04 & 57 & 4.99 & 61.77 & 91 & 3.81 & 61.26 \\
25 & 5.81 & 54.05 & 58 & 8.04 & 50.94 & 92 & 9.12 & 52.56 \\
26 & 3.09 & 60.07 & 59 & 6.66 & 53.13 & 93 & 6.56 & 50.96 \\
27 & 8.15 & 50.21 & 60 & 7.99 & 52.78 & 94 & 6.07 & 58.94 \\
28 & 6.13 & 45.12 & 61 & 5.84 & 54.41 & 95 & 5.61 & 57.36 \\
29 & 6.20 & 45.44 & 62 & 6.71 & 52.80 & 96 & 6.62 & 54.86 \\
30 & 10.78 & 44.54 & 63 & 5.28 & 60.09 & 97 & 3.50 & 64.55 \\
31 & 6.61 & 46.17 & 64 & 5.24 & 55.94 & 98 & 1.56 & 59.49 \\
32 & 10.08 & 48.59 & 65 & 1.77 & 62.26 & 99 & 4.72 & 59.63 \\
33 & 10.61 & 46.69 & 66 & 3.15 & 64.05 & ALL & 6.53 & 51.33 \\
\hline
\end{tabular}

Note: A pattern is classified as permanent if is observed in each year between 2009 and 2014 and as one-time if it is observed only in one year. Note that there are no exports in HS 77 recorded.

\section{Export patterns and characteristics of destination countries}

Békés and Muraközy (2012) build a theoretical model of heterogeneous firms to explain the prevalence of non-permanent export patterns. While a discussion of any details of this model is beyond the scope of this paper, it should be pointed out that the model yields a number of testable predictions that can be matched with evidence from the data at hand. One such hypothesis is that the likelihood of permanent trade (defined here as an export pattern represented by the six-digit string 111111) rises with proximity and market size of destination countries. ${ }^{6}$

To test this hypothesis empirical models are estimated. The dependent variable of the empirical model is either one (if the export pattern is classified as permanent) or zero. To test the hypothesis two versions of the empirical model are estimated. In the first version the dependent variable is zero if a firm-good-destination pattern is observed in one year only (i.e.

6 See Békés and Muraközy (2012), p. 240, prediction (E2). Note that predictions (E1) and (E3) refer to firm characteristics (productivity and capital costs). Given that the transaction data used here do not include information on these firm characteristics these hypotheses cannot be tested here. 
the pattern is $000001,000010,000100,001000,010000$ or 100000). In the second version the dependent variable is zero if the pattern is different from 111111. For short, version 1 tests permanent versus one-time exports, while version 2 tests permanent exports versus all other export patterns.

Proximity of the destination country to Germany is measured by the distance between Germany and the destination country of exports taken from the CEPII's GeoDist database (Mayer and Zignago 2011). The "distw" - measure is used that calculates the distance between two countries based on bilateral distances between the biggest cities of those two countries, those inter-city distances being weighted by the share of the city in the overall country's population (see Mayer and Zignago (2011, p. 11) for details).

Market size is measured by the Gross Domestic Product (GDP) of the country of destination, measured in Millions of US-Dollar in current prices. Information is taken from the World Bank World Development Indicators database. ${ }^{7}$

Besides proximity and market size the empirical model includes a number of control variables: 8

The EU has a number of bilateral trade agreements with (groups of) destination countries of exports. Given that these agreements can be expected to have an impact on the stability of export patterns a dummy-variable is included in the empirical model that takes on the value of one for destination countries with such an agreement. Here, custom unions, association agreements, stabilization agreements, (deep and comprehensive) free trade agreements and economic partnership agreements that were in force since 2009 or earlier are considered. ${ }^{9}$

The data does not include information on the mode of transport used for exporting. However, most of German long-distance trade is likely to involve shipping goods by sea. Therefore, the empirical model includes a dummy-variable for destination countries that are landlocked (with no direct access to a sea-port). Information is taken from the CEPII's GeoDist database (Mayer and Zignago 2011).

Some destination countries of exports have cultural and historical ties ${ }^{10}$ with Germany from the past that might have still an impact on the stability of export patterns. To control for these ties the empirical model includes a dummy-variable that indicated whether a destination country is a former German colony (although Germany lost all its colonies after World War I). Information is taken from the CEPII's GeoDist database (Mayer and Zignago 2011).

The transaction data include information on the value of the exports and on its weight. This can be used to compute unit values of exports by computing value over weight. Whether goods

\footnotetext{
7 See http://data.worldbank.org/indicator/NY.GDP.MKTP.CD.

8 I thank an anonymous referee for suggesting these variables. Given that these variables are used as control variables here only to test whether the hypothesis that the likelihood of permanent trade pattern increases within a firm with proximity and market size of destination countries holds we do not elaborate on these variables and the empirical results related to them.

9 Information is taken from European Commission - Directorate-General for Trade - Negotiations and agreements; see http://ec.europa.eu/trade/policy/countries-and-regions/negotiations-and-agreements/.

10 Note that the only linguistic ties that Germany has with non-EU countries is with Switzerland (where a relevant share of people speaks German) and, therefore, these ties are ignored here.
} 
are of high value or of low value might factor in the longevity of export relationships. Therefore, the unit value of exports is included in the empirical model.

Descriptive statistics for all variables included in the empirical model are reported in Table 3 for the three groups of exports patterns (permanent, one-time, all non-permanent). Compared to one-time exports and to all other exports, destination countries of permanent exports on average are closer to Germany, have a larger GDP, have more often a trade agreement with the EU, and are more often land-locked, while former colonial ties are rarer and the unit values of exports are larger.

Each empirical model includes firm fixed effects to control for unobserved firm characteristics that are not available in the transaction data (but that are important according to the model presented by Békés and Muraközy (2012), like productivity and capital costs). The estimated regression coefficients, therefore, refer to the within-firm variation of stability of export patterns over time due to variation in proximity and market size of the destination country.

The empirical models are estimated by Ordinary Least Squares, i.e. a Linear Probability Model is used. ${ }^{11}$ Results are reported in Table 4. In line with theoretical hypotheses, the

Table 3: Descriptive statistics for variables used in the econometric models by patterns of export of German firms with non-EU countries (firm-HS6-good-destination, 2009-2014)

\begin{tabular}{llllll}
\hline & Mean & sd & p1 & p50 & p99 \\
\hline Pattern: Permanent (N =583,995) & & & & & \\
Log(distance) & 8.13 & 1.09 & 6.30 & 8.48 & 9.68 \\
Log (GDP) & 13.26 & 1.77 & 9.08 & 13.37 & 16.54 \\
Trade agreement (Dummy) & 0.34 & 0.47 & 0.00 & 0.00 & 1.00 \\
Landlocked (Dummy) & 0.20 & 0.40 & 0.00 & 0.00 & 1.00 \\
Colonial ties (Dummy & 0.004 & 0.060 & 0.00 & 0.00 & 0.00 \\
Unit value of exports & 0.0003 & 0.089 & $5.00 \mathrm{e}-7$ & 0.0004 & 0.00264 \\
\hline Pattern : One-time (N =4,596,946) & & & & & \\
Log(distance) & 8.19 & 0.99 & 6.30 & 8.42 & 9.68 \\
Log (GDP) & 12.80 & 1.94 & 8.15 & 13.05 & 16.54 \\
Trade agreement (Dummy) & 0.29 & 0.45 & 0.00 & 0.00 & 1.00 \\
Landlocked (Dummy) & 0.18 & 0.39 & 0.00 & 0.00 & 1.00 \\
Colonial ties (Dummy & 0.0095 & 0.097 & 0.00 & 0.00 & 0.00 \\
Unit value of exports & 0.00023 & 0.0051 & $3.91 \mathrm{e}-7$ & 0.00003 & 0.0027 \\
\hline Pattern: All others (N = 8,361,037) & & & & & \\
Log(distance) & 8.18 & 1.01 & 6.30 & 8.42 & 9.68 \\
Log (GDP) & 12.87 & 1.91 & 8.39 & 13.05 & 16.54 \\
Trade agreement (Dummy) & 0.29 & 0.46 & 0.00 & 0.00 & 1.00 \\
Landlocked (Dummy) & 0.18 & 0.39 & 0.00 & 0.00 & 1.00 \\
Colonial ties (Dummy & 0.008 & 0.0896 & 0.00 & 0.00 & 0.00 \\
Unit value of exports & 0.00023 & 0.0048 & $4.00 \mathrm{e}-7$ & 0.00003 & 0.0027 \\
\hline
\end{tabular}

Note: A pattern is classified as permanent if is observed in each year between 2009 and 2014 and as one-time if it is observed only in one year. All non-permanent patterns are classified as "all others". For a definition of the variables see text. p1, p50, p99 refer to the $1^{\text {st }}, 50^{\text {th }}$ and $99^{\text {th }}$ percentile of the distribution of the variable. Note that minimum and maximum values are confidential because they (may) refer to a single firm.

11 See Wooldridge (2010), section 15.2, for a discussion of the linear probability model (LPM) for binary response variables. Note that the LPM allows the inclusion of a large number of firm fixed effects. The estimated standard errors here are clustered at the level of the firm. 
likelihood of permanent trade patterns increases within a firm with proximity and market size of of destination countries. Note that this holds while other characteristic of the destination country of exports (free-trade agreements with the EU, landlocked countries, former colonial ties with Germany) and the unit values of exports are controlled for. ${ }^{12}$

Table 4: Permanent versus temporary exports to non-EU countries and characteristics of destination countries, Germany 2009-2014

\begin{tabular}{|c|c|c|c|}
\hline \multirow{2}{*}{$\begin{array}{l}\text { Goods } \\
\text { Pattern }\end{array}$} & & \multicolumn{2}{|l|}{ All goods } \\
\hline & & $\begin{array}{l}\text { permanent [1] } \\
\text { versus } \\
\text { one-time [0] }\end{array}$ & $\begin{array}{l}\text { permanent [1] } \\
\text { versus } \\
\text { all others [0] }\end{array}$ \\
\hline $\begin{array}{l}\text { Log (Distance to } \\
\text { Germany) in km }\end{array}$ & $\begin{array}{l}\beta \\
\mathrm{p}\end{array}$ & $\begin{array}{r}-0.020 \\
0.000\end{array}$ & $\begin{array}{r}-0.012 \\
0.000\end{array}$ \\
\hline $\begin{array}{l}\text { Log (Gross Domestic } \\
\text { Product) in Million US-\$ }\end{array}$ & $\begin{array}{l}ß \\
\mathrm{p}\end{array}$ & $\begin{array}{l}0.021 \\
0.000\end{array}$ & $\begin{array}{l}0.013 \\
0.000\end{array}$ \\
\hline $\begin{array}{l}\text { Trade-agreement with } \\
\text { EU (Dummy; } 1 \text { = yes) } \\
\text { Landlocked }\end{array}$ & $\begin{array}{l}\beta \\
\mathrm{p} \\
\beta\end{array}$ & $\begin{array}{l}0.013 \\
0.000 \\
0.015\end{array}$ & $\begin{array}{l}0.009 \\
0.000 \\
0.010\end{array}$ \\
\hline $\begin{array}{l}\text { (Dummy; } 1=\text { yes) } \\
\text { Colonial ties with Germany }\end{array}$ & $\begin{array}{l}\mathrm{p} \\
ß\end{array}$ & $\begin{array}{l}0.000 \\
0.008\end{array}$ & $\begin{array}{l}0.000 \\
0.006\end{array}$ \\
\hline $\begin{array}{l}\text { (Dummy; } 1 \text { = yes) } \\
\text { Unit value of exports }\end{array}$ & $\mathrm{p}$ & $\begin{array}{l}0.036 \\
0.015\end{array}$ & $\begin{array}{l}0.006 \\
0.016\end{array}$ \\
\hline & $\mathrm{p}$ & 0.000 & 0.000 \\
\hline Constant & ß & $\begin{array}{l}0.002 \\
0.861\end{array}$ & $\begin{array}{r}-0.010 \\
0.195\end{array}$ \\
\hline Firm fixed effects & & yes & yes \\
\hline R-squared & & 0.250 & 0.135 \\
\hline $\begin{array}{l}\text { Number of firm-good-country } \\
\text { combinations }\end{array}$ & & $5,540,941$ & $8,945,032$ \\
\hline Number of firms & & 178,568 & 188,581 \\
\hline
\end{tabular}

Note: The dependent variable is either 1 (if the pattern of export participation is 111111, i.e. the firm-HS6-gooddestination country pattern is observed in each year between 2009 and 2014 (permanent)) or zero (if the firm-HS6good-destination country pattern is either observed only in one year (one-time) or if the pattern is not equal to 111111 (all others); for a definition of the export participation pattern see Table 1. For the definition of the variables see text. The empirical models are estimated by Ordinary Least Squares (i.e. a Linear Probability Model is used); for a discussion see text. Standard errors are clustered at the level of the firm.

\section{$5 \quad$ Concluding remarks}

This paper uses information on all export transactions of goods by German firms with countries outside the European Union from 2009 to 2014 to document for the first time the patterns of export participation at the firm-good-destination level over time and to investigate the link between the duration of export patterns and characteristics of destination countries. In line with

12 Both versions of the empirical model were estimated for patterns of goods from nine HS1-groups separately, too. The likelihood of permanent trade patterns increases within a firm with proximity and market size of destination countries in each group of goods. Details are available from the author on request. 
results for other countries, it turns out that permanent export patterns tend to be rare. Only 6.5 percent of all combinations were recorded in each year while more than half of all patterns are only observed once. In line with theoretical hypotheses the likelihood of permanent trade patterns increases within a firm with proximity and market size of destination countries. This holds when other characteristics of the destination countries and the unit values of exports are controlled for.

Acknowledgement All computations were done at the research data center of the Federal Statistical Office in Wiesbaden. The transaction level data used are strictly confidential and can be used inside the research data center of the Federal Statistical Office on Germany only. Researchers who want to use the data should visit www.forschungsdatenzentrum.de for more information or send a mail to Melanie.Scheller@destatis.de. To facilitate replication the Stata do-file used is available from the author on request. I thank two anonymous referees and the editor for helpful comments on an earlier version that helped to improve the paper considerably. 


\section{References}

Álvarez, Roberto, Hasan Faruq, and Ricardo A. López (2010). Is previous export experience important for new exports? Central Bank of Chile Working Paper 599. https://www.tandfonline.com/doi/abs/10.1080/00220388.2012.720368

Amador, Joao and Luca David Opromolla (2010). The margins of exports: firms, products and destinations. Economics Bulletin (Banco de Portugal), Spring, 103-119.

Békés, Gábor and Balázs Murakösy (2012). Temporary trade and heterogeneous firms. Journal of International Economics 87 (2), 232-246. https://www.sciencedirect.com/science/article/pii/S0022199611001711

Blum, Bernardo S., Sebastian Claro, and Ignatius J. Horstmann (2013). Occasional and perennial exporters. Journal of International Economics 90 (1), 65-74. https://www.sciencedirect.com/science/article/pii/S0022199612001717

Buono, Ines and Harald Fadinger (2012). The micro dynamics of exporting: evidence from French firms. Banca D'Italia Temi di Discussione Number 880.

https://ideas.repec.org/p/bdi/wptemi/td_880_12.html

Damijan, Joze P., Jozef Konings, and Saso Polanec (2014). Import churning and export performance of multi-product firms. The World Economy 37 (11), 1483-1506. https://onlinelibrary.wiley.com/doi/full/10.1111/twec.1

Esteve-Pérez, Silviano, Francisco Requena-Silvente, and Vincente J. Pallardó-Lopez (2013). The duration of firm-destination export relationships: evidence from Spain, 1997-2006. Economic Inquiry 51 (1), 159-180. https://onlinelibrary.wiley.com/doi/abs/10.1111/j.1465-7295.2012.00460.x

Geishecker, Ingo, Philipp Schröder, and Allan Sorensen (2017). One-off export events. https://papers.ssrn.com/sol3/papers.cfm?abstract_id=2897476

Hamermesh, Daniel S. (2000). The craft of labormetrics. Industrial and Labor Relations Review 53 (3), 363-380. https://www.jstor.org/stable/2695964?seq=1\#page_scan_tab_contents

Mayer, Thierry and Soledad Zignago (2011). Notes on CEPII's distance measures: The GeoDist database. CEPII Document de Travail No 2011-25, December.

http://www.cepii.fr/CEPII/en/publications/wp/abstract.asp?NoDoc=3877

Nitsch, Volker (2009). Die another day: duration in German import trade. Review of World Economics 145 (1), 133-154. https://econpapers.repec.org/paper/cesceswps/_5f2085.htm

Rahu, Siim (2015). The role of uncertainty for export survival: evidence from Estonia. The University of Tartu FEBA Working Paper. https://ideas.repec.org/p/mtk/febawb/97.html

Wagner, Joachim (2016). A survey of empirical studies using transaction level data on exports and imports. Review of World Economics 152 (1), 215-225. https://link.springer.com/article/10.1007/s10290-015-0235-8

Wooldridge, Jeffrey M. (2010). Econometric Analysis of Cross Section and Panel Data. Second Edition. Cambridge, Massachussetts and London, England: The MIT Press 


\section{Economics}

Please note:

You are most sincerely encouraged to participate in the open assessment of this article. You can do so by either recommending the article or by posting your comments.

\section{Please go to:}

http://dx.doi.org/10.5018/economics-ejournal.ja.2018-54

The Editor 